\title{
Pelatihan Pemanfaatan E-Learning Berbasis Website Bagi Guru Pendidikan Teknik Otomotif Di Kota Kupang
}

\author{
Priyono, Edy Suprapto, Fahrizal, Basri K \\ Program Studi Pendidikan Teknik Mesin, FKIP, Universitas Nusa Cendana \\ Email: mr.priyono007@gmail.com
}

\begin{abstract}
The change in learning models from conventional to online due to the impact of the COVID-19 pandemic has changed the way of thinking, methods used, paradigms and learning approaches that prioritize independent learning online with internet facilities. Through the internet all information is available, but it still has to be shared and sorted according to the needs and information to be taught to students. For this reason, competent teachers are needed, not only pedagogically, socially and professionally, but also required to master learning technology. This training is conducted to train teachers in planning, designing, developing and operating webside-based e-learning in the learning process that will be carried out with their students. The training method is designed with an online training and face-to-face approach. The approach uses hands-on exercises, tutorials and follow-up consultations. The results of the training showed an increase in the knowledge and skills of teachers about learning media. Before the training, the average understanding of teachers about learning media got a value of 52, while after being given training it became 84 . Then seen from the skills of making media, before training teachers could not create website-based media, but after being given training teachers could create and develop media webside based learning.
\end{abstract}

Keywords: e-learning, webside training, SMK teachers.

\begin{abstract}
Abstrak
Perubahan model pembelajaran dari Konvensional menjadi daring akibat dampak pandemi covid 19 telah mengubah cara berpikir, meotde yang digunakan, paradigma dan pendekatan pembelajaran yang lebih mengedepankan belajar mandiri secara online dengan sarana internet. Melalu internet semua informasi tersedia, namun tetap harus disharing dan dipilah sesuai kebutuhan dan informasi yang hendak diajarkan kepada siswa. Untuk itu dibutuhkan guru yang berkompeten bukan saja secara pedagogik, sosial dan profesional tetapi juga ditutnut untuk menguasai teknologi pembelajaran.namun sejauh ini penggunaan media internet dengan berbagai platform e-learning masih menjadi masalah bagi sebagian guru termasuk guru SMK di kota Kupang. Pelatihan ini dilakukan guna melatih guru dalam merencanakan, mendesain, mengembangkan dan mengoperasikan e-learning berbasis webside dalam proses pembelajaran yang akan dilakukan bersama siswa-siswinya. Metode pelatihan didesain dengan pendekatan pelatihan dan tatap muka secara daring. Adapun pendekatannya menggunakan latihan langsung, tutorial dan konsultasi lanjutan. Hasil pelatihan menunjukan adanya peningkatan pengetahuan dan ketrampilan guru tentang media pembelajaran. Sebelum adanya pelatihan, rata-rata pemahaman guru tentang media pembelajaran memperoleh nilai 52, sedangkan setelah diberi pelatihan menjadi 84. Kemudian dilihat dari ketrampilan membuat media, sebelum pelatihan guru tidak dapat membuat media berbasis website, tetapi setelah diberi pelatihan guru dapat membuat dan mengembangkan media pembalajaran berbasis webside.
\end{abstract}

Kata Kunci: E-learning, pelatihan Webside, Guru SMK.

\section{PENDAHULUAN}

Pengaruh globalisasi yang membawa perubahan positif pada salah satu bidang IPTEK yaitu dengan meningkatnya kemajuan ilmu pengetahuan dan teknologi. Pendidikan sebagai salah satu sendi yang terdampak sangat dirasakan khususnya pada masa Pandemi Covid 19 yang mana sangat tidak memungkinkan untuk dilakukannya proses pembelajaran secara langsung dengan model tatap muka (Luar Jaringan).

Terbatasanya model pembelajaran tatap muka pada masa pendemi bukan menjadi penghalang agar pembelajaran tidfak berlangsung, namun justr muncul berbagai inovasi dan teknologi serta strategi guna mengoptimlkan pembelajaran pada masa yang seraba terabtasa ini. Dari situasi ini kemudian, bisa ditemukan bahwa banyak bermunculan teknologi dan media bantu berbasis internet yang mencoba mengoptimlakna minimnya pembelajaran tatap muka menhjadi model pembelajaran daring (online).

Meski demikian, Fakta di lapangan, masih terdapat beberapa kendala yang menghambat dunia pendidikan. Diantaranya siswa/siswi tidak 
bisa mendapatkan informasi secara tepat dan jelas. Pihak sekolah juga tidak dapat melakukan promosi secara cepat kepada khalayak luas. Dalam penyampaian materi pembelajaran guru terkesan statis dan monoton, menjadikan suasana belajar mengajar yang kurang efektif, efisien, dan menarik. Oleh karena itu, dibutuhkan sebuah metode pembelajaran yang efektif dan efisien untuk meningkatkan mutu kualitas pendidikan, salah satunya adalah $e$ learning. E-learning merupakan cara baru dalam proses belajar mengajar yang menggunakan media internet sebagai sistem pembelajarannya.

Berdasarkan hasil observasi awal yangdilakukan terhadap model pembelajaran online di beberapa SMK khususnya pada bidang ilmu teknik mesin di Kota Kupang menunjukkan fakta bahwa sekitar $31 \%$ Guru atau tenaga pendidik belum memaksimalkan ELearning terutama berbasis Website, dikarenakan sebagian belum menguasai prosedur penggunaan IT seperti pengoperasian E-Learning. Fakta lain juga ditemukan bahwa beberapa SMK yang ada di Kota Kupang, dikemukakan bahwa kenyataan yang hampir sama yaitu masih banyak siswa yang belum memiliki keahlian yang memadai dalam mengakses atau menyesuaikan diri dengan pembelajaran lewat media internet atau secara E-learning. Kendala lain yang dialami juga berupa kekurangan ketersediaan media baik dalam bentuk Website, serta juga akses materi belajar untuk tingkat SMK yang masih mahal. Hal lain juga muncul dari kemampuan guruguru yang terbatas dalam memberikan materi lewat Media internet.

Padahal jika guru memiliki tingkat inovasi yang tinggi, maka saat ini upaya membuat dan memanfaatkan website sebagai media pembelajaran ini tidaklah terlalu sulit karena sudah banyak CMS (conten manajemen system) seperti Wordpress, Jombla, Moodle yang dapat dimanfaatkan secara gratis. Tapi sayangnya fasilitas tersebut belum banyak dimanfaatkan secara baik oleh masyarakat, khususnya oleh guru atau lembaga dalam menginformasikan lembaga atau institusinya melalui sebuah website online. Dan salah satu faktor penting kenapa hal tersebut terjadi adalah karena ketidak mampuan dalam membuat dan memanfaatkan teknologi internet untuk membuat sebuah website yang dapat diakses seluruh masyarakat dimanapun berada dan kapan pun.

Melihat perkembangan fenomena ini, program Studi pendidikan Teknik mesin FKIP Undana tergerak ikut bertanggung jawab dalam upaya mengejar ketertinggalan guru-guru SMK Teknik Mesin di Kota Kupang dalam memanfaatkan teknologi informasi ini, khususnya teknologi internet, sebagai salah satu wujud tri dharma perguruan tinggi khususnya dalam bidang pengabdian pada masyarakat. Dengan memberikan pelatihan membuat website sekolah. Diharapkan akan dimilikinya kemampuan dan ketrampilan baru teknologi informasi di pembuatan website sebagai media pembelajaran e-learning.

\section{METODE}

Metode kegiatan Pengabdian kepada Masyarakat ini dilaksanakan dalam bentuk pelatihan pembuatan media pembelajaran berbasis website, dengan langkah-langkah kegiatan sebagai berikut:

\section{Persiapan}

Hal-hal yang dilakukan dalam persiapan kegiatan antara lain: 1) melakukan koordinasi dengan tim PKM untuk pembagian tugas, 2) melakukan koordinasi dengan pihak Sekolah (SMK teknik mesin di Kota Kupang, 3) membuat proposal kegiatan, 4) membuat materi kegiatan, 5) membuat instrument monitoring seperti soal pretes-posttest, dan instrument keterlaksanaan program mulai dari tahap perencanaan, pelaksanaan, monev, dan tindak lanjut.

2. Pelaksanaan Kegiatan/pelatihan

Setelah perencanaan disusun, langkah selanjutnya adalah melaksanakan kegiatan yang dirancang selama 3 hari.

3. Monitoring dan Evaluasi Kegiatan

Monitoring pada kegiatan PKM ini dilaksanakan mulai dari perencanaan, pelaksanaan, dan evaluasi. Instrumen yang digunakan adalah instrument keterlaksanaan perencanaan, pelaksanaan, dan evaluasi kegiatan pengabdian kepada masyarakat dan instrument tes pemahaman tentang media pembelajaran berbasis Website. Sedangkan 
evaluasi pada kegiatan pengabdian kepada masyarakat ini ditinjau dari aspek keterlaksanaan dan aspek ketercapaian tujuan. Aspek keterlaksanaan program seperti keterlaksanaan perencanaan, pelaksanaan, dan evaluasinya. Kemudian aspek ketercapaian tujuan seperti ketercapaian pemahaman dan ketrampilan guru dalam membuat media pembelajaran berbasis website.

\section{HASIL DAN PEMBAHASAN}

Kegiatan Pelatihan pembuatan website sebagai media pembelajaran e-learning bagi guru pendidikan Teknik Mesin di Kota Kupang dilaksanakan secara daring menggunakan zoom meeting yang dimulai pada hari Kamis, 05 Juli sampai sabtu 07 Juli 2021 yang dimulai pukul 09.00 - 13.00 WIB. Narasumber juga memberikan bantuan layanan melalui whatshapp untuk diskusi terkait dengan pembuatan website sebagai media pembelajaran e-learning tersebut.

Kegiatan ini diikuti oleh sebanyak 20 peserta yang semuanya terdiri dari guru pada jenjang pendidikan Menengah Kejuruan di kota Kupang. Kegiatan pelatihan pembuatan website sebagai media pembelajaran e-learning bagi guru ini dilaksanakan secara daring dengan menggunakan Zoom Meeting, dan dibantu menggunakan aplikasi whatshapp untuk hal-hal yang ingin ditanyakan lebih lanjut.

Tahapan pelatihan pembuatan website sebagai media pembelajaran e-learning yaitu melalui tiga tahap yaitu tahap persiapan, pelatihan dan monitoring. Kegiatan pelatihan ini diawali dengan pembukaan dan pemaparan singkat dari ketua pelaksana Priyono, S.Pd., M.Si., kemudian dilanjutkan pemaparan dari narasumber lain yaitu Edy Suprapto. (Dosen Program Studi Pendidikan Teknik Mesin FKIP Undana) yang memaparkan terkait media pembelajaran e-learning di masa pandemi, berikutnya Fahrizal (Dosen Pendidikan Teknik Mesin FKIP Undana) memaparkan materi tentang pembelajaran berbasis web, dan Basri K. (Dosen Pendidikan Teknik Mesin Undana) yang membahas tentang Pembuatan sebuah Website.

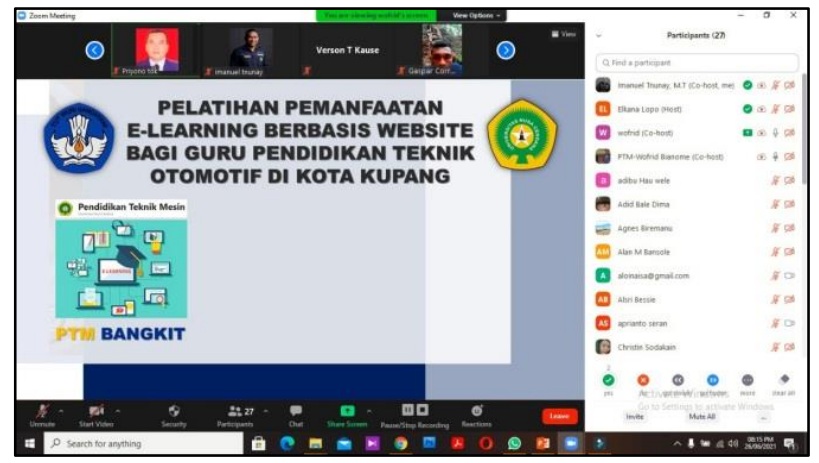

Gambar 1. Narasumber sedang memberikan materi pelatihan pembuatan website sebagai media pembelajaran e-learning

Peserta nampak antusias mendengarkan dan mencoba mempraktekkan materi yang disampaikan oleh beberapa narasumber, peserta juga cukup aktif bertanya terkait dengan langkah-langkah dan beberapa hal teknis lainya dalam membuat sebuah website sebagai media pembelajaran e-learning di sekolah

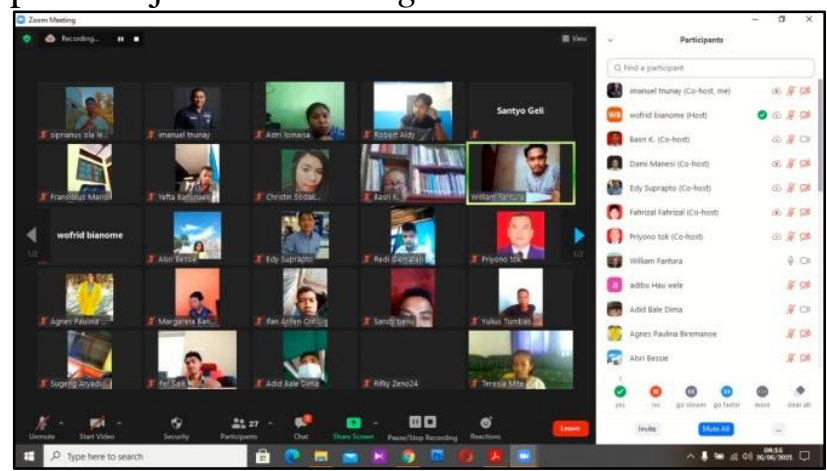

Gambar 2. Peserta kegiatan Pelatihan

Pembuatan Website sebagai media pembelajaran e- learning.

Di akhir kegiatan untuk melihat hasil dan masukan dari seluruh peserta kegiatan maka dilakukan evaluasi dengan menggunakan menggunakan google form secara online. Dari jumlah peserta yang mengikuti kegiatan sebanyak 20 peserta, lembar evaluasi yang berhasil terisi dari google form sebanyak 20 peserta. Berikut hasil evaluasi yang diperoleh dari peserta setelah mengikuti kegiatan pelatihan pembuatan website sebagai media pembelajaran e-learning, dengan hasil sebagai berikut:

1. Kemampuan beradaptasi

Kemampuan beradaptasi dilakukan untuk mengetahui seberapa intens dan sering seorang guru mendengar, melihat dan mengalami perubahan kondisi pembelajaran 
dari model konvensional menjadi model pembelajaran blanded dengan dipadukan dengan modul e-learning

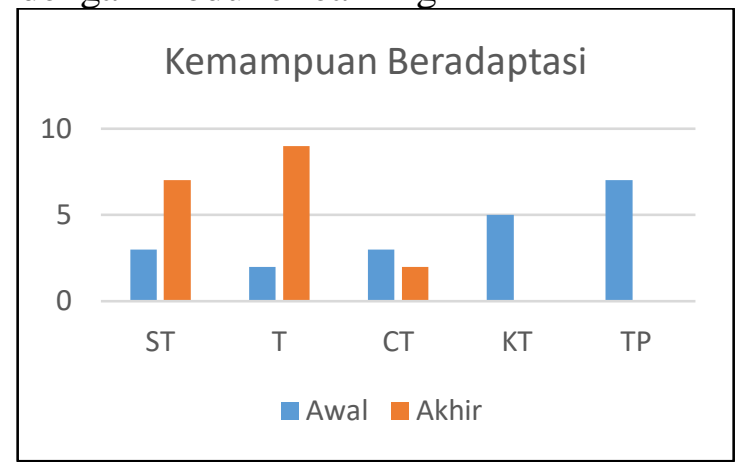

Gambar 3. Diagram Kemampuan Beradaptasi

Kemampuan akhir beradaptasi guru SMK yang menigikuti pelatihan sepert pada gambar 3 diatas menunjukkan bahwa pada tahap awal jumlah peserta yang tidak paham (TP) lebih dominan, namun kondisi ini berubah pada akhir kegiatan dimana yang terbentuk pada peserta adalah kemampuan dilvel cukup terbiasa, terbiasa dan sangat terbiasa. Ini menunjukkan bahwa hasil pelatihan mengubah mainset dan kemampuan beradaptasi guru dengan internet dan elearning berbasis webside makin baik. Pada tahap ini juga peserta sudah mulai diperkenalkan dengan berbagai bentuk platform e-learning untuk pembelajaran online.

2. Kemampuan membuat e-learning

Pada fase ini, peserta dilatih untuk mendesain dan membuat model e-learningnya sendiri dengan dibantu oleh narasumber dengan berbagai metode yaitu dengan praktik langsung, video tutorial dan konsulotasi via media sosial.

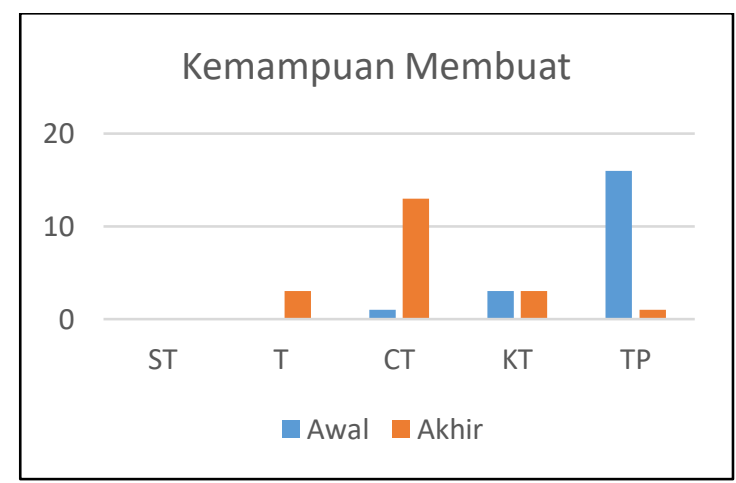

Gambar 4. Diagram kemampuan Membuat Elearning
Gambar 4 diatas menunjukkan bahwa pada tahap awal kemampuan guru untuk membuat e-learning sangat rendah (Tidak Paham). Namun jumlah itu menurun diakhir kegiatan bahkan terdapat beberapa guru yang sudah pada tahap terampil dalam membuat elearning berbasis webside.

3. Kemampuan mengembangkan e-leraning Pata fase ini, peserta dianggap sudah pada fase tertinggi dan bisa untuk membuat dan memodifikasi laman e-learningnya masingmasing sesuai dengan konsep kebutuhannya saat mengajar di kelas.

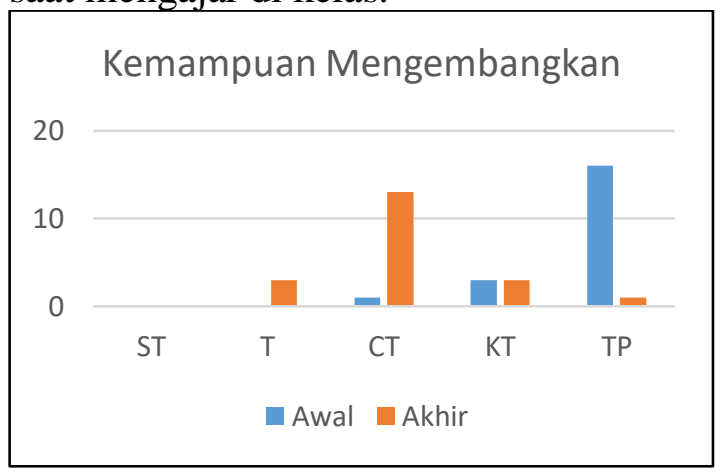

Gambar 5. Kemampuan mengembangkan

$$
\text { e-learning }
$$

gambar 5 diatas menunjukan bahwa meskipun ditahap awal kemampuan membuat dan mendesain serta mengembangkan e-learning masih rendah, namun pada akhir tahap kegiatan, beberapa guru sudah mencapai level terampil dan cukup terampil.

4. Kemampuan mengoperasikan e-learning

Kemampuan mengoperasikan berkaitan dengan kemampuan guru mengintegrasikan media (e-learning berbasis webside) yang sudah direncanakan, dibuat dan dikembangkan sesuai dengan konten pembelajarannya mampu untuk dioperasikan dan meningkatkan kualitas pembelajaran di kelas.

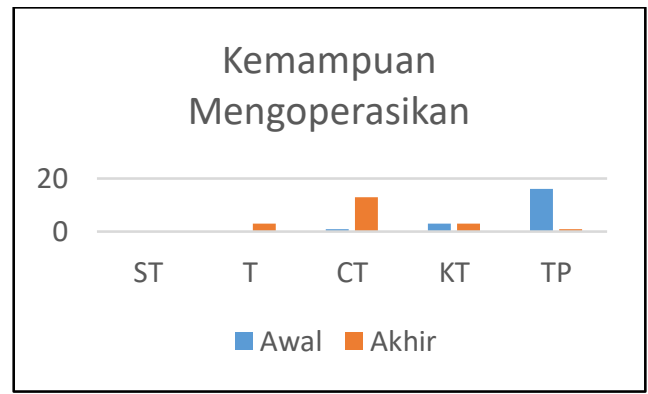

Gambar 6. Diagram peningkatan kemampuan mengoperasikan E-Learning 
Gambar 6 menunjukkan bahwa pada fase awal kegiatan pelatihan hanya terdapat beberapa guru yang bisa mengoperasikan elearning meskipun masih dalam konsep elearning yang sangat sederhana. Hasil kegiatan pelatihan diakhir menunjukkan bahwa lebih dari setengah peserta pelatihan sudah mencapai target dimana mereka sudah mampu mengintegrasikan media yang dikembangkan untuk mendukung proses pembelajaran secara daring.

Berdasarkan hasil pelatihan terhadap 20 orang guru SMK jurusan Teknik Mesin diperoleh beberapa produk e-learning yang berhasil dibuat dan dikembangkan seperti berikut :

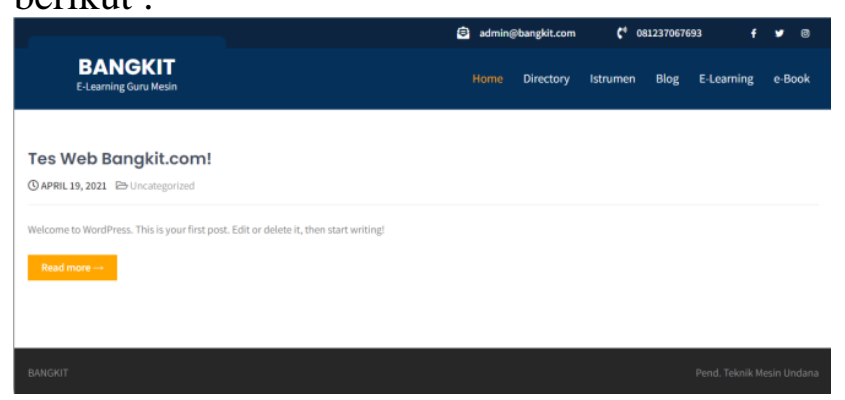

Gambar 7. Produk Antar Muka Webside

E-learning Bangkit

Webside dikembangkan dengan system domain dan hosting pada server domainesia. Platform web didesain dan dikembangkan menggunakan wordpress dengan template education corner. Web memiliki 6 laman utama yang terdiri dri Home, Directory, Isntrumen, Blog, E-learning dan E-Book.

\begin{tabular}{|c|c|}
\hline Home & $\begin{array}{l}\text { Sebagai domain laman, berisi } \\
\text { informasi-informasi seputar } \\
\text { penggunaan webside }\end{array}$ \\
\hline Directory & $\begin{array}{l}\text { Berisikan informasi- } \\
\text { informasi yang berkaitan } \\
\text { dengan kekhususan bidang } \\
\text { ilmu teknik mesin dan } \\
\text { turunannya }\end{array}$ \\
\hline Instrumen & $\begin{array}{l}\text { Kumpulan perangkat } \\
\text { pembelajaran dan merupakan } \\
\text { meda sharing diantara Guru }\end{array}$ \\
\hline & $\begin{array}{lcr}\text { Teknik } & \text { Mesin } & \text { yang } \\
\text { mengampu } & \text { mata } & \text { pelajaran } \\
\text { yang sama } & & \end{array}$ \\
\hline Blog & $\begin{array}{l}\text { Personal domain yang berisi } \\
\text { konten-konten khusus dan } \\
\text { sepesifik dari setiap guru dan }\end{array}$ \\
\hline
\end{tabular}

mata pelajaran yang diampuny

E-learning : Platform Pembelajaran yang berisi informasi dan semua hal yang berkenan dengan pembelajaran dengan konten utama yaitu activities, participant, media sharing, media social, evaluasi, dan time spend

E-Book : Berisi kumpulan Buku-buku referensi yang dapat diakses oleh siswa dan guru dari sekolah yang terkibat dalam kegiatan e-learning ini

Selain produk Laman Web juga tersedia produk Laman Blog peserta yang berhasil dibuat dan dikembangkan :

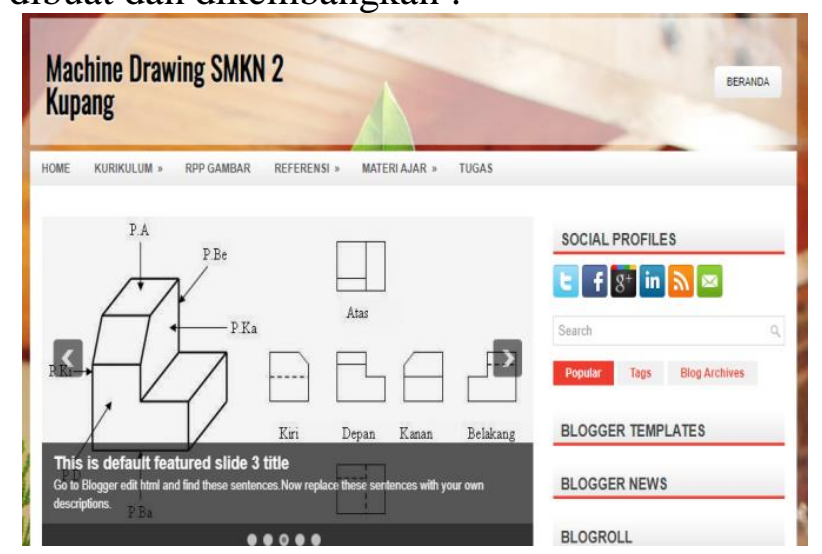

Gambar 8. Blog Guru SMK Negeri 2

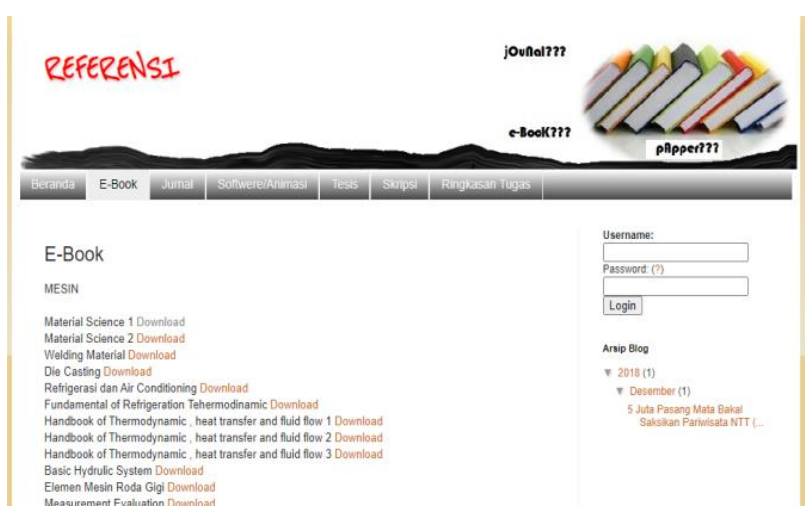

Gambar 9. Blog Guru SMK Nageri 2 Atambua

Output dari kegiatan pengabdian kepada masyarakat ini yang dilakukan melalui pelatihan pembuatan website sebagai media pembelajaran e-learning adalah guru menjadi lebih memiliki pemahaman, kemampuan dan ketrampilan dalam membuat sebuah website sebagai media pembelajaran e-learning di sekolah, sehingga 
pembelajaran dapat dilakukan secara lebih efesien dan efektif dimasa pandemi Covid-19 dan kualitas pembelajaran diharapkan dapat menjadi meningkat.

\section{KESIMPULAN}

Berdasarkan hasil pengabdian disimpulkan bahwa keberhasilan suatu pembelajaran di kelas salah satunya dipengaruhi oleh pemanfaatan media pembelajaran yang baik, mudah dimanfaatkan dan menarik. Disamping itu kemampuan menguasai media pembelajaran e-learning yang menarik sangat penting bagi guru khsususnya untuk memudahkan guru dan siswa dalam pembelajaran daring dimasa pandemi covid-19. Dan melalui pelatihan ini peserta memiliki pemahaman dan kemampuan dalam membuat sebuah website sebagai media pembelajaran elearning

\section{SARAN}

Berdasarkan simpulan diatas, maka hendaknya penggunaan e-learning dapat dilakukan secara intens dengan terlebih dahulu mensosialisasikannya kepada peserta didik. Disamping itu juga guru juga perlu untuk terus memperkaya diri dengan leatihan secara terus menerus dan memperkayan dan mengupgrade konten materi serta menyesuaikannya dengan perkembangan (uptodate) ilmu yang sedang dipelajari.

\section{UCAPAN TERIMA KASIH}

Ucapan terima kasih disampikan kepada FKIP Undana sebagai pemberi dana penelitian.

\section{DAFTAR PUSTAKA}

Arsyad, Azhar. (2011). Media Pembelajaran. Jakarta: Raja Grafindo Persada

Dananjaya, Utomo. (2002).Media Pembelajaran Aktif. Bandung: Tiga serangkai.

Manesi, D. (2017). Desain Modul Tes Offline Dengan Mengoptimalkan Tools Power Point. Komodo Jurnal Pendidikan Teknik Mesin, 1(1), 16-24.

Manesi, D. (2020). Efektivitas Penggunaan Web Sebagai Media Pembelajaran Online Mahasiswa Pendidikan Teknik Mesin Pada Mata Kuliah Elemen Mesin
1. Komodo Jurnal Pendidikan Teknik Mesin, 4(1), 8-14.

Priyono, Bagia, Manesi Damianus (2014). Integrasi learning management system (LMS) dalam pembuatan test berbasis WEB.Undana Press, Seminar Nasional Sains dan Teknik Undana 2. B151B161

Rahmad Widiyanto \& Asmad Community (2011). Mudah Membangun Website Formal Secara Pro Dengan Joombla". Jakarta: PT. Elex Media Komputindo

Rahmat Hidayat (2010). Cara Praktis Membangun Website Gratis. Jakarta: PT. Elex Media Komputindo

Sanjaya, Wina. (2009) Strategi Pembelajaran.Bandung: Tiga serangkai.

Sudjana, N. dan Rivai, A.(2005) Media Pengajaran. Bandung : Sinar Baru Algesindo.

Susilana, R., \& Riyana, C. (2008) Media pembelajaran: hakikat, pengembangan, pemanfaatan, dan penilaian. CV. Wacana Prima.

Tri Wibowo, Agung, Isa Akhlis, Sunyoto Eko Nugroho.(2014) Pengembangan LMS (Learning Management System) Berbasis Web untuk Mengukur Pemahaman Konsep dan Karakter Siswa". Scientific Journal of Informatics Vol. 1, No. 2, November : 127-137. 